\title{
UMA ANÁLISE SEMIÓTICA DO DESIGN GRÁFICO RETRÔ: OS ANÚNCIOS DO EVENTO “MAXIMÍDIA 2010" A SEMIOTIC ANALYSIS OF THE RETRO GRAPHIC DESIGN: THE ADS OF THE EVENT "MAXIMÍDIA 2010"
}

\author{
Rafael Peduzzi Gomes \\ UniRitter Laureate International Universities \\ rafaelpeduzzi@gmail.com \\ César Steffen \\ UniRitter Laureate International Universities \\ cesarsteffen@gmail.com \\ Vinicius Gadis Ribeiro \\ UniRitter Laureate International Universities \\ vinicius@uniritter.edu.br \\ Ygor Corrêa \\ UniRitter Laureate International Universities \\ correaygorprof@gmail.com
}

Resumo: 0 termo retrô surgiu no século XX, sendo hoje possivelmente banalizado como estilo gráfico, então, este estudo visa a compreender o conceito de retrô enquanto fenômeno no campo do design gráfico. Para tanto, são abordados aspectos formais e simbólicos do design gráfico, assim como investiga-se o retrô etimológica e historicamente. Adota-se a semiótica peirceana como base metodológica para analisar o conjunto de anúncios da campanha publicitária do evento MaxiMídia 2010. A partir da análise, inferiu-se que o retrô não trata apenas dos aspectos sígnicos de ícone e índice, associados a referências do passado, sendo interpretado apenas como símbolo. Nesse sentido, a campanha analisada, ao fazer uma reciclagem de estilos a partir da ironia e da nostalgia reflexiva, contempla algumas definições de retrô propostas pela literatura.

Palavras-chave: semiótica, design gráfico, estilo, retrô, campanha publicitária.

Abstract: The term retro appeared in the twentieth century, and today is possibly banalized as a graphic style. In this study, it is intended to understand retro as a phenomenon, analyzing how it is presented in graphic design. For that, formal and symbolic aspects of graphic design are approached, and retro is etymologically and historically investigated. Peircean semiotics is used as a methodological basis for analyze the set of ads for the advertising campaign of the event MaxiMídia 2010. According to the analysis, the retro deals not only with the signic aspects of icon and index, with references to the past, but is only interpreted as a symbol. It was considered that the campaign, by doing a recycling of styles from the irony and reflective nostalgia, covers some definitions of retro proposed by the literature.

Keywords: semiotics, graphic design, style, retro, advertising campaign.

\section{Considerações iniciais}

O termo retrô surgiu no século XX para descrever retornos ou resgates na arte, no design e na cultura popular diferentes de movimentos anteriores, como o Renascimento e o Revivalismo. Na atualidade, o retrô tem sido observado como um 
estilo gráfico e diferencial de produtos, sendo um possível recurso para designers. Diante disso, é imperativo que a área do Design Gráfico atente para esse fenômeno contemporâneo, de forma a produzir conhecimento e contribuir para uma possível compreensão conceitual relativa a elementos gráficos e significações relacionadas ao retrô em peças gráficas.

O objeto de estudo é a conhecida campanha publicitária para o evento MaxiMídia 2010, em São Paulo. 0 evento é descrito em seu website como "a grande vitrine da indústria da comunicação em todo o Brasil" e "o maior evento do setor em toda a América Latina" (MAXIMÍDIA, 2015), reunindo um fórum, uma feira e um prêmio. Assim, este é um estudo qualitativo e descritivo, baseado em pesquisa bibliográfica, que tem por objetivo compreender a constituição do retrô como um fenômeno no design gráfico. Para tanto, são considerados os aspectos simbólicos do design gráfico como mediador das relações sociais e é realizada uma abordagem etimológica e histórica do retrô, a partir da literatura da área. Como aporte metodológico, foi elencada a semiótica peirceana, a fim de analisar o que se pode considerar como retrô no design gráfico a partir do objeto de estudo. Na análise, também são abordados elementos de design gráfico e publicidade e o conceito de ironia.

Este artigo está dividido em: 2. Conceitos de design gráfico; 3. Retrô: uma abordagem etimológica e histórica; 4. A semiótica como aporte teóricometodológico; 5. Pressupostos metodológicos; 6. Análise semiótica; e 7. Considerações finais. A seguir, são apresentadas postulações teóricas relativas ao conceito de design gráfico.

\section{Conceitos de design gráfico}

Nesta seção, são apresentadas definições do que se entende por design gráfico, adotadas aqui como base para a análise proposta. Neste horizonte, Bürdek (2006) aponta que o design é onipresente nos ambientes cotidianos - casa, trabalho, transporte público, vestimenta - e, por isso, conclui que discutir o que é ou não design já não é uma questão, pois esse, ao estar em tudo, media a comunicação entre pessoas e grupos sociais. Além disso, Fiell e Fiell (2001) consideram o design de forma global, ou seja, como concepção e planejamento 
global de produtos, diferente do estilo, ligado à aparência e ao tratamento da superfície - qualidades expressivas de um produto. Assim, o estilo é frequentemente um elemento complementar de uma solução de design.

Estendendo ao design gráfico, Villas-Boas (2003) o conceitua como atividade profissional e área de conhecimento, cujo objeto é a elaboração de projetos para reprodução por meio gráfico de peças comunicacionais, como cartazes, livros e folhetos. Essa elaboração está ligada a um ordenamento estéticoformal de elementos textuais e não-textuais, compondo uma peça gráfica. VillasBoas (2003) acrescenta que um objeto só pode ser considerado fruto de design gráfico quando contempla os aspectos: (1) formais, nos quais há a combinação de elementos como ilustração, tipografia, fotografia e grafismos em uma perspectiva projetual, que visa a reprodução a partir de um original; (2) funcionais, que se referem à finalidade de comunicar uma mensagem para um observador por meio de elementos textuais e não-textuais, a fim de persuadir, guiar ou vender; (3) metodológicos, que se referem à necessidade de uma metodologia projetual; e (4) simbólicos, que tratam da função subjetiva, relacionada à fetichização das mercadorias, cujo valor se forma apenas pelas relações sociais humanas.

Em consonância com os autores citados, este estudo aborda os aspectos formais e simbólicos, ou seja, a qualidade expressiva do design gráfico em relação às formas e a sua função subjetiva. Dessa forma, na próxima seção, é abordado o conceito de retrô.

\section{Retrô: uma abordagem etimológica e histórica}

A escolha pelo retrô como tema se dá por ser recorrente hoje em diversos meios (BAKER, 2013): na moda, nos produtos, na música, no design gráfico, com a apropriação de estilos, técnicas, grafismos, tipografias, ilustrações e imagens antigas. Busca-se, no design gráfico, dar conta desse fenômeno atual, pouco abordado na pesquisa acadêmica (BAKER, 2013), em uma abordagem etimológica e histórica.

Inicialmente, no que tange à dimensão etimológica, é proposto um breve panorama sobre o termo retrô, a partir das definições presentes em 5 dicionários 
de Português ${ }^{1}$. Percebeu-se que seu uso ainda não é normatizado, visto que constou em apenas um dicionário (FERREIRA, 2010), referindo-se a veste, decoração, estilo que se baseie em épocas passadas. Há, em todos, o prefixo "retro" ou "rétro", relacionado a "atrás", "para trás", a palavras como retrógrado e retroativo, e a ideias de retorno ao passado e imitação ou retomada de estilo ou comportamento do passado. Na Wikipedia ${ }^{2}$, consta que a palavra retrô advém do prefixo latino "retro", que significaria "para trás" ou "em tempos passados", e também é uma abreviação do vocábulo francês “retróspectif”. Posto isso, considerase que as definições de dicionários são um ponto de partida, mas insuficientes, visto que os signos linguísticos de uma língua orgânica, neste caso, o Português, estão em um processo contínuo de ressignificação (SAUSSURE, 2006). Assim, propõe-se a seguir uma abordagem histórica do retrô.

Nesse sentido, Guffey (2006) relaciona o termo "retrô" aos primeiros revivais do Art Nouveau nos anos 60, na Europa e nos Estados Unidos. A autora enfatiza a diversidade de sentidos do termo, ligado a gostos pessoais e culturais, à obsolescência tecnológica e a estilos de épocas, como sinônimo de antiquado ou velho. No entanto, o retrô começou a representar um passado mais próximo no início dos anos 70, e apenas no fim da década passou a se assemelhar a hoje: meio nostálgico, meio irônico, retoma diferentes períodos e detalhes históricos de forma misturada, num passeio caótico (GUFFEY, 2006). Assim, pode ser confundido com um mero olhar para trás, mas pode servir para conciliar-se com o passado moderno a partir de sua reinterpretação.

Por sua vez, Baudrillard (1995) trata o retrô em relação à entrada da história como mito e referencial perdido no cinema, a partir de filmes que reproduzem costumes antigos e recriam situações de forma obcecada pela absoluta fidelidade histórica, o que, para o autor, é o que esgota qualquer significado. Em outra perspectiva, Meggs e Purvis (2009) descrevem, no design gráfico, o retrô com "interesse deslavadamente eclético pelo design europeu modernista da primeira metade do século" (2009, p. 616). Esse interesse, a partir

\footnotetext{
${ }^{1}$ Foram consultados os dicionários Aurélio, Houaiss, Michaelis, Enciclopédia Barsa e Dicionário Barsa, cujas edições estão detalhadas nas referências deste trabalho.

2 Foram consultados os verbetes "Retrô", em <http://pt.wikipedia.org/wiki/Retr\%C3\%B4>, e "Retro Style", em <http://en.wikipedia.org/wiki/Retro_style>. Acesso em: 05/07/2016.
} 
dos anos 80, seria chamado de retrô principalmente em Nova York, e também envolveria o desacato a regras tipográficas e fascínio por tipografias excêntricas. Os autores consideram o retrô como um aspecto do pós-modernismo, a partir do seu interesse por retomadas históricas e sua busca em diversas fontes do design moderno entre guerras para reagir aos próprios dogmas. Já em se tratando do design retrô atual, Rohenkohl (2011, p. 151-152) cita que "Está ligado à releitura, paródia, citação ou sátira do passado, muitas vezes parecendo como algo ingênuo ou mesmo utilizando-se do humor", e diferencia termos relacionados:

a) antiguidade: É o objeto próprio do passado, contido de valor histórico; b) réplica: É o objeto produzido hoje, imitando fielmente um objeto específico particular do passado ou não;

c) vintage: É o objeto que foi do passado, incorporado no repertório atual. É um fato muito presente do segmento da moda;

d) retrô: É o objeto produzido hoje, inspirado nas características formais do estilo do passado, com processos de fabricação atuais. De modo geral, indica em uma peça algumas características do passado, ou seja, envolve uma reciclagem de estilos.

Além disso, Boym (2001) e Wilson (2005) consideram a definição de "nostalgia", cuja origem remete ao século XVII, em que se definia a condição médica de soldados e estudantes suíços, que sentiam, após longas viagens, saudade de seus lares e pátrias. Inicialmente considerada uma doença, a nostalgia envolveria sintomas diversos e, a partir do século XIX, foi se transformando em sentimento, sinônimo de saudade do passado, ânsia por um tempo diferente, pela infância. Boym (2001) distingue "nostalgia restauradora" de "nostalgia reflexiva"3: a restauradora pode ser vista em filmes como Barry Lyndon, com uma recriação fidelíssima do passado, citada aqui por Baudrillard; já a nostalgia reflexiva baseiase na criação da atmosfera ou aura de uma época passada.

Ademais, Oliveira (2012) aponta que, na sociedade de hoje, os produtos de consumo são mais valorizados por suas associações, significados e valores do que pela satisfação de necessidades, logo, "o significado se torna argumento comercial e ferramenta mercadológica" (OLIVEIRA, 2012, p. 5), apelando para as sensações felizes experimentadas pelo consumidor no passado, formando uma cultura de consumo retrô, voltada aos valores simbólicos dos produtos. Nesse sentido, percebe-se o uso do retrô como uma ferramenta estilística para evocar significados

\footnotetext{
${ }^{3}$ Tradução nossa de "restorative nostalgia" e "reflective nostalgia" (BOYM, 2001, p. 41).
} 
do passado, buscando associar o objeto a lembranças agradáveis. A existência do livro O Retrô no Design Gráfico (RAIMES; BHASKARAN, 2007) corrobora com isso, visto ser um manual de como reproduzir estilos gráficos do passado de 1860 a 1989, com descrições, contextos históricos e tutoriais de como recriar, digitalmente, os elementos de cada estilo.

Diante das perspectivas dos autores, foram inferidas características do retrô, aqui sumarizadas como subsídios para a análise proposta: produzido no presente, inspirado em características formais de estilos do passado; ligado à releitura, citação ou paródia do passado; busca de forma despretensiosa e irônica elementos para compor uma aura de uma época; gesto estilístico dentro do design que resgata de forma distanciada elementos do passado e produz significados no presente; está em aspectos globais e locais, populares e de luxo; meio nostálgico, meio irônico, retoma períodos e elementos históricos de forma caótica. Assim, são expostos a seguir os conceitos de semiótica.

\section{A semiótica como aporte teórico-metodológico}

Segundo Peirce (2000), a semiótica, aqui apresentada de forma resumida, é baseada na observação junto da abstração, a fim de extrair conclusões a respeito dos signos. Santaella (2004) afirma que Peirce se baseia na fenomenologia, entendendo tudo o que aparece à mente e à percepção como fenômeno, e define três ciências normativas: a estética, que estuda os ideais que guiam os sentimentos; a ética, que estuda os ideais que orientam as condutas; e a lógica ou semiótica, que estuda ideais e normas que conduzem o pensamento - logo, a linguagem, os signos e significações (SANTAELLA, 2004).

Nesse sentido, Santaella (2004) trata da gramática especulativa, primeira ramificação da semiótica, como sendo uma ciência geral dos signos, que estuda o que faz um processo poder ser considerado como signo. Assim, essa serve a uma análise do signo nos três aspectos da representação: a significação, analisando o signo em si mesmo e nas suas propriedades internas que podem significar; a objetivação, analisando a referência àquilo que ele indica, representa; e a interpretação, analisando os efeitos que o signo pode despertar nos receptores. Assim, segundo Santaella (2004, p. 7), a semiótica de Peirce é triádica, com três 
elementos formais e universais que aparecem à percepção e à mente em todos os fenômenos: primeiridade, secundidade e terceiridade.

\begin{abstract}
A primeiridade aparece em tudo que estiver relacionado com acaso, possibilidade, qualidade, sentimento, originalidade, liberdade, mônada. A secundidade está ligada às idéias de dependência, determinação, dualidade, ação e reação, aqui e agora, conflito, surpresa, dúvida. A terceiridade diz respeito à generalidade, continuidade, crescimento, inteligência. A forma mais simples da terceiridade, segundo Peirce, manifesta-se no signo, visto que o signo é um primeiro (algo que se apresenta à mente), ligando um segundo (aquilo que o signo indica, se refere ou representa) a um terceiro (o efeito que o signo irá provocar em um possível intérprete).
\end{abstract}

Dessa forma, segundo Peirce (2000, p. 46), "um signo é aquilo que, sob certo aspecto ou modo, representa algo para alguém". Santaella (2004) afirma que o signo ou representamen pode ser qualquer coisa que represente outra, e essa coisa representada pelo signo é chamada de objeto, enquanto o impacto gerado pelo signo no público é chamado de interpretante. Nesse sentido, Santaella (2004) aponta que Peirce estabelece uma distinção entre objeto dinâmico, ou a coisa representada pelo signo, e objeto imediato do signo, ou o modo como o signo representa a coisa, classificado na tricotomia ícone, índice e símbolo. 0 ícone se fundamenta em uma qualidade, podendo sugerir seu objeto por semelhança com outra qualidade - um azul-claro remete ao céu. Já o índice se fundamenta na existência concreta de seu objeto, indicando-o - fumaça indica fogo. No caso do símbolo, o fundamento é uma lei, e seu objeto é representado por convenções - o hino e a bandeira são símbolos que representam um país, como o Brasil, que pode ser símbolo de diversos objetos - samba, América do Sul, democracia - que, por sua vez, também podem ser símbolos que remetem a outros objetos. Tal cadeia de representações demonstra a complexidade da semiose, o processo de significação ou atribuição de significado, citado por Santaella (2004) como ininterrupto. Posto isso, na próxima seção, são expostos os pressupostos metodológicos do estudo.

\title{
5. Pressupostos metodológicos
}

Este estudo, baseado em pesquisa bibliográfica, é de enfoque qualitativo, posto que explora um processo indutivo, de explorar e descrever, e é de alcance descritivo, pois busca especificar propriedades e características de um fenômeno a ser analisado (SAMPIERI; COLLADO, LUCIO, 2013). O objeto de análise é a 
campanha publicitária do evento MaxiMídia 2010, selecionada tendo em vista que seus anúncios se mostram relevantes não só pela popularidade na web, estando, por exemplo, nos primeiros resultados internacionais do Google quando se buscou, em 05/12/2017, por "retro ads", mas também por contemplarem elementos gráficos, verbais e conceituais a respeito do retrô. Além disso, a escolha pelo objeto de estudo se deu por conveniência, visto que as imagens dos anúncios podem ser acessadas online em boa resolução, o que permite uma análise baseada em observá-las. A análise semiótica, portanto, contempla o conjunto de quatro anúncios de página dupla para o evento MaxiMídia 2010. Seus dados de veiculação não estão disponíveis, porém, por sua diagramação, infere-se que sejam voltados a revistas. Também há na internet imagens dos anúncios traduzidos para o inglês. A criação é creditada à agência Moma Propaganda e a ilustração ao 6B Estúdio 4 .

Como aporte teórico-metodológico, foi elencada a semiótica (PEIRCE, 2000), a fim de um aprofundamento nas significações e nos elementos que representam o retrô. Mais especificamente, são abordados, na análise, os conceitos da gramática especulativa, primeira ramificação da semiótica (SANTAELLA, 2004), que trata dos três aspectos da representação de um signo - significação, objetivação e interpretação - e a segunda tricotomia, relacionada ao objeto imediato - ícone, índice e símbolo. Além dos conceitos semióticos elencados para análise, Santaella (2004, p. 6) aponta que, devido a sua generalidade como ciência, uma análise semiótica "reclama pelo diálogo com teorias mais específicas dos processos de signos que estão sendo examinados". A autora acrescenta que não é possível analisar peças publicitárias sem conhecimentos de sintaxe visual e design. Destarte, somou-se à análise, apresentada na seção seguinte, elementos de design gráfico, a fim de combinar a semiótica com conhecimentos específicos.

\section{Análise semiótica}

Para fins de melhor visualização, é mostrado aqui, de forma completa, apenas um (Figura 1) dos quatro anúncios, que seguem o mesmo layout.

\footnotetext{
${ }^{4}$ Mais informações em www.momapropaganda.com.br e www.6bestudio.com.br.
} 
Figura 1: Anúncio “Facebook” em página dupla, campanha MaxiMídia 2010.

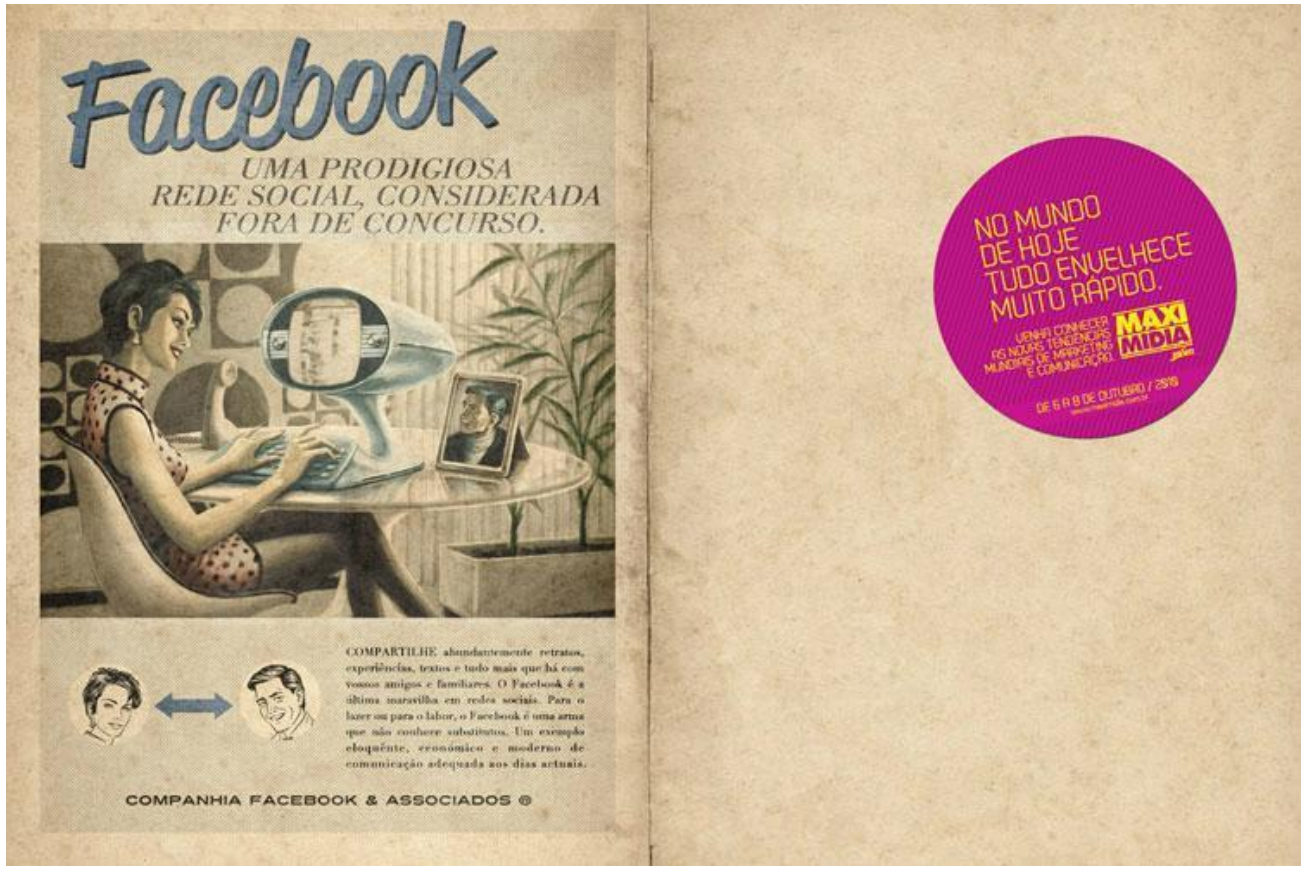

Fonte: Moma Propaganda, 2016

Em seguida, são apresentados os outros anúncios do conjunto, apenas a partir de suas páginas esquerdas ou pares (Figura 2), que mudam de acordo com a temática.

Figura 2: Páginas pares dos outros anúncios da campanha MaxiMídia 2010.

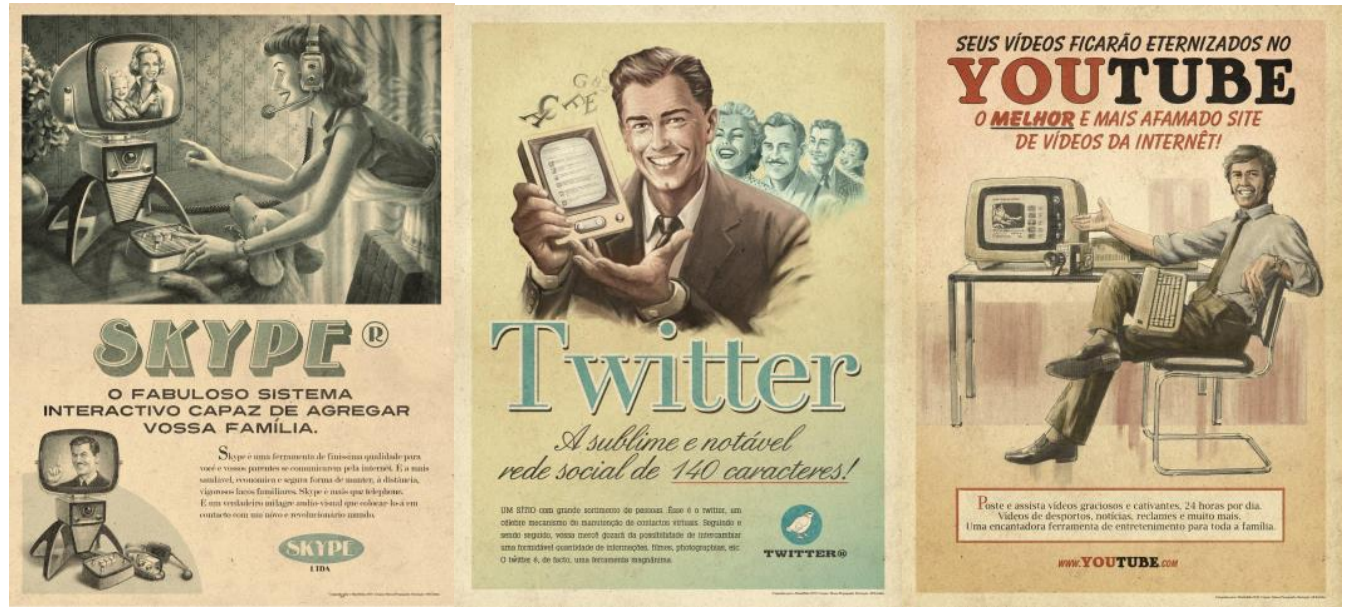

Fonte: Moma Propaganda, 2016.

A seguir, são analisados, a partir da semiótica, elementos do design gráfico, desde sua significação e objetivação até a interpretação, e na tricotomia de ícone, índice e símbolo. 
Quanto a cores e a textura, percebe-se o uso de cores suavizadas e dessaturadas, quase em preto e branco, junto a uma textura amarelada de papel envelhecido, que unifica os anúncios, como um ícone de velho, antigo. Percebe-se que se buscou manter, como índices, as cores das corporações como, por exemplo, o YouTube, na cor vermelha. A cor da mensagem na página ímpar, à direita, com tipografia em amarelo sobre um círculo de cor magenta com textura de linhas diagonais, contrasta em cor e textura com o anúncio em geral, colocando a mensagem da campanha como mais atual - colorida, em cores vivas - frente a um ambiente mais antigo - em cores desbotadas, numa ambientação sépia ou preto e branco. Já as padronagens são usadas como índices, em papéis de parede, nos anúncios de Facebook e Skype, nos quais se vê- um padrão orgânico de plantas e flores, possível índice de estampas de um passado ornamental, como no movimento Arts and Crafts, do fim do século XIX. Ao fundo do anúncio Facebook, em destaque, vê-se o premiado padrão Geometri1, criado em $1960^{5}$.

No anúncio, são usadas tipografias de diversos estilos. Também na tipografia, é reforçado o contraste entre a mensagem na página ímpar e o conteúdo da página par. À esquerda, há o ícone de uma organização tipográfica do passado, com a variedade de tipos já descrita e, inclusive, com mensagens escritas como índices de uma forma antiga de expressão verbal. Mesmo que o foco do estudo seja a linguagem visual, pôde se constatar que a linguagem verbal usa palavras com grafia anterior a pelo menos 1943 (PORTAL DA LÍNGUA PORTUGUESA, 2016), como "telephone", "actuais", "photographias" e até uma adaptação: "Internêt". Comentários sobre a tradução em inglês também citam a linguagem datada ou vintage ${ }^{6}$. Já na página ímpar, usa-se apenas um tipo, mais contemporâneo, e numa linguagem verbal sem referências ao passado.

Também podem ser analisados os logotipos que foram criados para cada rede social especialmente para os anúncios. Sua composição em geral e também a alternativa de nome, de Facebook para Companhia Facebook \& Associados, são ícones de antigas formas de uso de logotipos e nomes. Já as ilustrações dos

\footnotetext{
${ }^{5}$ Informações e imagens em: <https://tinyurl.com/geometri1>. Acesso em: 15/11/2017.

Alguns comentários disponíveis em: <http://tinyurl.com/InventorSpotAds> e $<$ http://drprem.com/marketing/vintage-ads-but-not-vintage-ads.html>. Acesso em: 15/07/2016.
} 
anúncios retratam, como índices, pessoas que estariam usando, em dispositivos, as redes sociais anunciadas; o estilo adotado é realista, num formato ícônico do passado, visto que, na atualidade, percebe-se, como mais recorrente, o uso da fotografia para essas peças. Observam-se, também, o uso da técnica contemporânea de pintura digital e as referências à tecnologia nos anúncios, como índices. Todos os anúncios retratam computadores e dispositivos do passado, como símbolos da velha forma de ver o futuro.

O layout das páginas da esquerda pode ser interpretado como uma mistura de referências - ícones e índices. Apesar disso, configura-se, de forma simples, sem muita integração de texto e imagem e com diferenciação clara de título, subtítulo, ilustração, descrição do produto e assinatura, além da mensagem da campanha localizada na página à direita, claramente contrastante com o todo de cada anúncio. Percebe-se no modo como os anúncios buscam transmitir significados - seu objeto imediato - também um índice e símbolo do passado. Muniz (2005, p. 6) menciona que "os anúncios que continham informações sobre o produto deram lugar a outros que incorporaram um imaginário que associa o produto a um estilo de vida", como um afastamento da visão de mercadorias como utilidades com valor de uso em direção a uma visão de mercadoria como valor sígnico (MUNIZ, 2005). Nos anúncios analisados, percebe-se o uso dessa estratégia antiga de comunicação, focada em mostrar informações sobre o produto e seu valor de uso, só compreendida como símbolo pelo conhecimento de tal convenção.

Nesse sentido, percebe-se que a interpretação simbólica da campanha como retrô passa pelo entendimento de sua ironia, que contrasta a linguagem antiquada da página à esquerda - tratada quase como um cartaz - com uma marca contemporânea à direita, ainda acompanhada do slogan: No mundo de hoje tudo envelhece muito rápido. Essa ironia se encontra também no ato de produzir, para divulgar um evento sobre comunicação e mídia, uma propaganda de redes sociais - caracterizadas como contemporâneas, novidades, ainda mais em 2010, data da campanha - com ícones e índices, referências a propagandas do passado. 0 conceito de ironia usado se baseia em Moisés (2004, p. 247), que a define como "dizer o contrário do que se pensa, mas dando-o a entender". A ironia, assim, é uma forma de humor que usa contraste e dualidade para perturbar seu interlocutor 
através de ambiguidade, que só pode ser interpretada a partir do contexto. Assim, a estética do passado se apresenta aqui não como simplesmente antiga ou como meros anúncios antigos, mas como um símbolo, uma paródia do velho jeito de vender as novidades, usando, ironicamente, um tema atual, as redes sociais. A partir do slogan da campanha, de um evento para discutir mídias e tecnologias, estabelece-se uma crítica irônica, implícita, ao próprio campo: as novidades do presente logo serão velhas e, logo, não podem ser vistas com olhos do passado.

Portanto, o retrô no anúncio é representado não só pelo aspecto formal do design gráfico, mas tem uma significação com uma aura antiga, cuja objetivação, baseada em ícones e índices do passado, leva a uma interpretação subjetiva no seu aspecto simbólico, a partir do contexto e da forma geral de comunicar a mensagem, como retrô. Assim, a compreensão do contexto por trás do conteúdo é que faz com que, como símbolo, o retrô seja um signo interpretado através da compreensão da ironia por trás do anúncio, que referencia o passado para passar uma mensagem do presente. Se forem consideradas apenas as qualidades e indícios visuais dos anúncios, pode-se ter a impressão de que é apenas uma peça antiga. Porém, é necessário leitura e interpretação a partir de conhecimento prévio para compreender o anúncio. Dessa forma, considerando a intenção da comunicação publicitária de persuadir através da mensagem, infere-se que o receptor do anúncio compreenderia, além dos aspectos icônicos e indiciais em referência ao passado, os seus aspectos simbólicos, representantes de uma peça retrô. Pertencendo este receptor também ao campo da comunicação e do marketing, compartilharia o repertório de convenções necessário a tal interpretação.

Ademais, o interesse eclético do retrô descrito por Meggs e Purvis (2009) se tornou evidente nos anúncios analisados. Na campanha, o interesse não é apenas em um período passado, como no início do movimento retrô, mas, sim, em uma retomada irônica (MOISÉS, 2004) e nostálgica (BOYM, 2001; WILSON, 2005), que mistura diferentes períodos e detalhes históricos num passeio caótico (GUFFEY, 2006) e, de acordo com Rohenkohl (2011), passando uma mensagem com referências de diferentes épocas, numa reciclagem de estilos que é releitura, citação, sátira e paródia do passado. Nesse sentido, a nostalgia (BOYM, 2001; WILSON, 2005) foi considerada aqui como abarcada pelo retrô, sendo a campanha 
mais adequada à nostalgia reflexiva, pois cria uma aura ou atmosfera de antigo. Assim, não se apresenta possível para a campanha a crítica de Baudrillard (1995) à obsessão em fazer uma recriação perfeita do passado, considerada como nostalgia restauradora. Em relação à ideia de Baudrillard (1995), em que a retomada histórica acaba com seu próprio significado, considera-se que o significado não é justamente imaginar como se pensaria nas coisas, mas sim a ficção que se cria para imaginar o que se imaginaria, que revela algo sobre a atualidade.

Assim, percebe-se que o uso do retrô, hoje em dia, tem por intenção geral imitar um estilo e fazer referências ao passado, buscando criar certa aura de "antigo", como visto na campanha. Essa referência ao passado pode ser específica em relação a uma forma de comunicação (MUNIZ, 2005), como é o caso, ou ser recurso estilístico, pretendendo um estilo para a mensagem a ser passada. Observa-se, empiricamente, que esse apelo ao retrô e a referências históricas se configura como recorrente na atualidade, em que os produtos de consumo são valorizados, principalmente por suas associações, significados e valores. Sendo assim, o retrô, além de recurso estilístico, torna-se um argumento comercial para marcas e produtos (OLIVEIRA, 2012).

\section{Conclusões}

Uma primeira ressalva a ser feita é a de que a fenomenologia peirceana se caracteriza, em última instância, por uma interpretação individual, o que torna a análise do objeto de estudo prenhe de subjetividades. Portanto, o processo de semiose pode levar a diferentes interpretações em análises semióticas feitas por outros pesquisadores. Esse estudo permitiu identificar que o retrô não está representado apenas nos elementos gráficos ou verbais, mas na própria forma de transmitir significados, ou seja, o objeto imediato. Isso vai de encontro a uma banalização do retrô como estilo gráfico, relacionado apenas a manipular os aspectos de ícone e índice dos signos, sugerindo ou indicando referências do passado, o que poderia acarretar um entendimento de que a peça é antiga e não retrô. $\mathrm{O}$ retrô pode estar na escolha de elementos, suportes e técnicas a serem usadas, podendo ser essa mesma um resgate, e envolve, principalmente, as 
convenções e contextos que dão as condições para algo ser um símbolo interpretado como retrô.

Sobre o termo retrô, já existe uma caracterização estabelecida (ROHENKOHL, 2011) que serviu para a análise. Mesmo assim, no cotidiano, os significados se confundem: no próprio site da agência que criou os anúncios, há um convite a baixar imagens das peças, citadas como "vintage" (MOMA PROPAGANDA, 2010), o que contradiz Rohenkohl (2011), que usa esse termo para caracterizar um objeto do passado incorporado a um repertório atual. Em última instância, pode-se pensar que toda peça de design gráfico tem sua parcela de retrô, na medida em que é uma conjunção de referências históricas e culturais, e que os estilos que se formam espontaneamente em algumas épocas podem vir a ser ressignificados em outras. 0 design dos anúncios propõe como seria a publicidade do fenômeno das redes sociais no passado, onde seriam retratadas como futuro. 0 que se torna claro é que tal imaginação ocorria num presente incontornável para os autores da campanha. Afinal, todo trabalho inspirado em outra época também é retrato da própria época em que se passa e de como se pensa o passado, analogamente à história como processo contínuo de interpretar e repensar velhos e novos relatos (DENIS, 2008). A abordagem retrô se apresenta, então, como um enfoque ou estilo mais específico de um trabalho de design ou publicidade, a ser considerado a partir do contexto ou realizada de forma intuitiva, pessoal (MEGGS; PURVIS, 2009).

Por fim, supõe-se que a combinação de ironia, tema atual e uma providencial tradução para o inglês foi o que tornou o anúncio tão conhecido na $w e b$. Considera-se que o retrô se configura como um fenômeno relevante que, a partir do caso MaxiMídia 2010, pode se tornar muito popular. Visto que é ininterrupto o processo de semiose, provocado pela interpretação e análise semiótica, são traçadas questões que podem guiar estudos futuros: seria o retrô um reflexo da grande quantidade de informação sobre o passado disponível e fácil de citar, reler e resgatar? Por esse excesso de informação, seria o retrô um sintoma de uma sociedade que não consegue conciliar o passado com o presente ou nega o presente? 0 retrô envolve uma idealização do passado? Seria essa idealização positiva ou negativa? O retrô denota falta de conhecimento do passado ou erudição, com múltiplas referências? Ou todos esses fatores são subordinados 
apenas ao uso do retrô como apelo a lembranças nostálgicas com fim mercadológico?

\section{Referências bibliográficas}

BAKER, S. E. Retro Style. New York: Bloomsbury Academic, 2013.

BAUDRILLARD, J. Simulacra and simulation. Ann Arbor: U.M. Press, 1995.

BOYM, S. The Future of Nostalgia. New York: Basic Books, 2001.

BÜRDEK, B. História, teoria e prática do design de produtos. SP: Blucher, 2006.

DENIS, R. C. Uma introdução à história do design. São Paulo: Blucher, 2008.

Dicionário Barsa. São Paulo: Barsa Planeta Internacional, 2003.

Enciclopedique Barsa. São Paulo: Barsa Planeta, 2012.

FERREIRA, A. B. H. Dicionário Aurélio da língua portuguesa. Coordenação Marina Baird Ferreira, Margarida dos Anjos. 5. ed. Curitiba: Positivo, 2010.

FIELL, C.; FIELL, P. 0 design do século XX. Köln: Taschen, 2001.

GUFFEY, E. Retro: The Culture of Revival. Londres: Reaktion Books, 2006.

HOUAISS, A.; VILLAR, M. S. Dicionário Houaiss da Língua Portuguesa. Rio de Janeiro: Objetiva, 2001.

MEGGS, P.; PURVIS, A. História do design gráfico. São Paulo: Cosac Naify, 2009.

MICHAELIS. São Paulo: Companhia Melhoramentos, 1998.

MOISÉS, M. Dicionário de termos literários. São Paulo: Cultrix, 2004.

MUNIZ, E. Comunicação publicitária em tempos de globalização. Canoas: Ulbra, 2005.

PEIRCE, C. S. Semiótica. 3.ed. São Paulo: Perspectiva, 2000.

RAIMES, J.; BHASKARAN, L. Design retrô. São Paulo: Editora Senac SP, 2007.

ROHENKOHL, R. Design retrô: um desafio da contemporaneidade em reconhecimento ao passado. Unoesc \& Ciência - ACSA, Joaçaba, v. 2, n. 2, p. 147153, jul./dez. 2011.

SAMPIERI, R. H.; COLLADO, C. F.; LUCIO, M. P. B. Metodologia de pesquisa. 5. ed. Porto Alegre: Penso, 2013.

SANTAELlA, L. Semiótica Aplicada. São Paulo: Pioneira Thomson Learning, 2004.

SAUSSURE, F. Curso de linguística geral. São Paulo: Cultrix, 2006.

VILLAS-BOAS, A. 0 que é [e o que nunca foi] design gráfico. RJ: 2AB, 2003.

WILSON, J. Nostalgia. Lewisburg: Bucknell University Press, 2005. 


\section{Outras fontes}

MAXIMÍDIA 2010. APRESENTAÇÃO. [O site não está mais disponível]. Link antigo: <http://tinyurl.com/MaxiMidia2010>. Acesso em: 22/06/2015.

MOMA PROPAGANDA. 2016. Disponível em: <https://tinyurl.com/MomaProp>. Acesso em: 15/07/2016.

OLIVEIRA, V. B. 0 consumo retrô: valorizando o passado, evocando emoções. 2012. Disponível em: <https://tinyurl.com/OlveiraVB2012>. Acesso em: 08/11/2017.

PORTAL DA LÍNGUA PORTUGUESA. 2016. Disponível em: <https://tinyurl.com/Acordo1943>. Acesso em: 15/11/2017. 